УДК 37

DOI $10.21661 / \mathrm{r}-464898$

\title{
B.В. Ковров
}

\section{СУБЪЕКТНАЯ ПОЗИЦИЯ КУРСАНТА В ОБУЧЕНИИ КАК УСЛОВИЕ УСПЕШНОСТИ В ПРОФЕССИОНАЛЬНО-ОБРАЗОВАТЕЛЬНОЙ ПОДГОТОВКЕ ИНСПЕКТОРА ПДН}

Аннотация: в статье даётся характеристика профессиональной деятельности инспектора по делам несовершеннолетних органов внутренних дел, осуществляющего социально-педагогические и психологические функиии по профилактике правонарушений среди несовершеннолетних в социальной среде. Профессионализм и компетентность инспектора ПДН определяется его субъектной позицией к прочессу обучения в ходе профессионально-образовательной подготовки курсанта в университете. Обосновывается, что эффективность профессиональной деятельности сотрудников ПдН определяется их сформированной субъектной позицией в прочессе освоения профессионально-образовательного опыта, что является главным условием его профессионализма в будущем.

Ключевые слова: инспектор по делам несовершеннолетних, профессиональная деятельность, субъектная позиция в образовании, профессиональная подготовка, образовательный опыт.

\section{V.V. Kovrov}

\section{CADET'S SUBJECTIVE POSITION DURING THE EDUCATION PROCESS AS A CONDITION FOR A SUCCESSFUL PROFESSIONAL AND EDUCATIONAL PREPARATION OF A JUVENILE INSPECTOR}

Abstract: the article describes professional activities of a juvenile inspector of internal affairs agencies who performs social, pedagogical and psychological functions to prevent juvenile delinquency in the social environment. The professionalism and competence of a juvenile inspector is determined by his subjective position towards the learning process in the course of the student's vocational and educational training 
at the university. It is substantiated that the effectiveness of the professional activity of staff of juvenile affairs is determined by their subject position in the process of mastering the professional and educational experience that is the main condition for their professionalism in the future.

Keywords: inspector for juvenile affairs, professional activity, subjective position in education, vocational training, educational experience.

Содержание образовательного опыта человека - часть культурного опыта человечества, опредмеченного в результатах познания (накопленном богатстве знаний человечества), в освоенных и передаваемых от человека к человеку умений (способов) организации деятельности, в том числе и способов создания новых продуктов (умений творческой деятельности), в нормах и правилах отношений и взаимоотношений, принятых в обществе, человеческом социуме и культуре. (по И.Я. Лернеру) Результатом освоения образовательного опыта принято считать образованность человека, понимаемую как его готовность к решению актуальных для человека жизненных и профессиональных задач.

Процесс обучения человека в образовательной организации системы или высшего (среднего) профессионального образования - это период его профессионально-личностного становления, осуществляемого в ходе накопления опыта деятельности в будущей профессиональной сфере, содержательная составляющая которого, определяется характером и спецификой профессии (профессиональной деятельности) осваиваемой студентом.

Современные реалии функционирования образовательных систем среднего и высшего профессионального образования свидетельствуют, что содержательно в основе различных образовательных программ СПО и ВПО, предлагаемых студенту к освоению, положены задачи формирования (развития) разнообразного профессионально-образовательного опыта, что и отражено в требованиях государственных образовательных стандартов, в образовательно-профессиональных программах подготовки специалистов разных профилей и направлений [5]. 
Личностно-профессиональное становление студента в вузе и обретение им личностно-значимых смыслов диалектически связанных с социально-значимыми конструктами, безусловно, возможно (и зависит) от уровня обретения им качественного опыта профессиональной деятельности. Это положение - ответ на вопрос: является ли образовательный процесс в вузе личностно-центрированным и субъектно-направленным, а не призрачно-имитационным и декларативным?

По сути, проектирование и реализация образовательного процесса в системе ВПО - должны обусловливаться необходимостью выделения специального (индивидуально-дифференцированного) актуального образовательного опыта, его максимального (насколько возможно) приращения в период обучения в вузе на основе развития субъектной позиции студента в учебной деятельности, что определяется личностными смыслами, её ценностью и значимостью. Именно субъектная позиция позволяет студенту перевести предлагаемое содержание в систему индивидуального образовательного опыта, сориентироваться в ценностных смыслах и личностных значениях образования, организующих впоследствии дальнейшую профессиональную деятельность. В этом случае период обучения студента в вузе становятся периодом его личностно-профессионального становления.

Субъектная позиция студента в обучении (как качественная характеристика), во-первых, отражает деятельностный уровень реализации ценностного отношения к выбранной профессиональной сфере своей жизнедеятельности, а, во-вторых, свидетельствует о мотивах и целях учебной деятельности и достигнутых результатах (успехах и достижениях).

Важность актуализации образовательной практики по развитию субъектной позиции обучающихся (далее курсантов и слушателей), нами рассматривается применительно к специальности 44.05.01 - Педагогика и психология девиантного поведения (специализация Социальная педагогика), осуществляемую ФГКОУ ВПО «Московский университет МВД России им. В.Я. Кикотя». Обучающиеся курсанты и слушатели по этой специальности - будущие сотрудники 
подразделений по делам несовершеннолетних (инспектора ПДН) органов внутренних дел. Содержание профессиональной деятельности инспектора ПДН заключается в проведении необходимой работы по социально-психолого-педагогической профилактике правонарушений среди несовершеннолетних и устранению причин и условий (потенциальных рисков и конкретных угроз), способствующих правонарушениям и антиобщественным действиям несовершеннолетних в различных социальных средах.

Многоаспектность деятельности инспектора ПДН проявляется на основе рассмотрения содержания его профессиональных функций, включающих: воспитательную, поисковую, коммуникативную, организационную, прогностическую, конструктивную [2]. Их системная реализация в профессиональной деятельности тем самым способствует формированию позитивного общественного мнения о деятельности ОВД среди населения в целом.

В специальных исследованиях концептуально определяются подходы в определении сущности категорий «профессионал», «психология профессионализма», определяются критерии, уровни, этапы профессионального развития человека [3], даётся профессиографическое описание деятельности специалистовпсихологов системы МВД [4], теоретическая модель профессиограммы инспектора по делам несовершеннолетних [2]. В профессиографических подходах к характеристике социально-педагогической деятельности сотрудника ОВД - инспектора по делам несовершеннолетних отмечаются его основные профессиональные функции $[1 ; 2]$.

В воспитательной (социиально-педагогической) деятельности инспектор ПДН:

- анализирует воздействие социально-педагогических факторов (явлений, событий, процессов), влияние психолого-педагогических условий и причин на результативность процессов воспитания, социализации и развития личности взрослеющего человека;

- осуществляет практическую деятельность по социально-психолого-педагогической и правовой помощи (поддержке) детям и подросткам, их родителям 
и лицам их замещающих (семье как институту социализации), защите их законных интересов и прав; инициированию государственных и общественных программ социального оздоровления, оптимизации влияния различных институтов социализации (семьи, детских и молодёжных объединений и организаций, СМИ и др.); координирует взаимодействие в данном направлении работы различных государственных организаций (учреждений, служб) с волонтёрскими инициативами различных гражданских сообществ;

- взаимодействует с различными категориями воспитуемых, в том числе в сложных социально-педагогических ситуациях; осуществляет контроль трудных жизненных (кризисных) ситуаций, предупреждает (способствует, оказывает помощь) в конструктивном разрешении межличностных конфликтов;

- использует средства социально-педагогического и психологического воздействия на межличностную и межгрупповую коммуникацию взрослеющего субъекта, его отношения с различными агентами социальной среды; осуществляет коррекцию асоциальных (антисоциальных) «воспитательных воздействий» на детей и подростков со стороны институтов формальной и неформальной социальной среды; координирует воспитательные воздействия просоциальных агентов среды, проектирует вариативную социальную и психолого-педагогическую поддержку детей и подростков;

- реализует гуманистически ориентированные психолого-педагогические технологии, направленные на гармоничное личностное развитие взрослеющих детей, формирует их устойчивую направленность на развитие паттернов конструктивного ненасильственного поведения, установок на здоровый образ жизни («жизнь без насилия и вредных привычек»), ответственной активности в отношении к окружающей природе, рукотворному материальному и социальному миру, продуктивном преодолении жизненных трудностей;

- оценивает конструктивность, реализуемых по месту жительства детей и подростков социальных программ, ориентированных на развитие духовно-нравственной устойчивости детей и подростков и формирование их гражданско-пра- 
вовой культуры, способствующих минимизировать влияние рисков асоциального и антисоциального поведения, предупреждать нарушения (отклонения) в личностных и социальных статусных характеристиках детей;

- обеспечивает успешность процесса ресоциализации детей и подростков с отклоняющимся поведением, адаптации девиантных и делинквентным подростков по окончании отбывания наказания в специальных учреждениях пенитенциарной сферы.

В диагностической и коррекционной деятельности инспектор ПДН:

- выявляет специфические особенности психических проявлений ребенка в его жизнедеятельности, психические образования соответствующие нормативным характеристикам данного возрастного этапа (с присущими ему факторами риска и «кризисами возраста»); принадлежность ребёнка к определённой социальной группе (гендерной, возрастной, социальной, этнической, религиозной);

- диагностирует психические процессы, психологические свойства и состояния взрослеющего человека, их характерологические (возможно вариативные проявления) в различных видах деятельности и социальном поведении человека;

- выявляет несовершеннолетних группы риска и осуществляет социальнопсихолого-педагогическую диагностику детей и подростков, направляемых в специальные исправительные учреждения пенитенциарной сферы;

- устанавливает причины девиантных поведенческих проявлений детей и подростков, кризисных ситуаций жизнедеятельности детей, социального неблагополучия семьи (социально-бытовые условия) и её социального окружения;

- воздействует на уровень развития и функционирования когнитивно-познавательной, потребностно-мотивационной, волевой сферы, характера, темперамента, личностных черт и акцентуаций, способностей и потребностей, психомоторики функциональных состояний, самосознания и самоактуализации.

Успешность профессиональной деятельности сотрудника подразделения ПДН, таким образом, во многом зависит от сформированности у него обозначен- 
ных компетенций, что затруднительно (невозможно) без учёта субъектной позиции курсанта (слушателя) в процессе обучения в вузе. Показатели выраженности субъектной позиции курсанта тесно связаны с организационно-методическими и психолого-педагогическими условиями развития данного личностного психического образования в учебном процессе, которыми становятся:

- во-первых, вычленение и осознание курсантом личностного смысла получаемого профессионального образования и формирование (оформленность в связи с этим) ценностного (субъектного) к нему отношения;

- во-вторых, накопление курсантом опыта конструктивного самопознания и саморазвития, самоанализа и самооценки своих потребностей и возможностей в ходе осуществления образовательного процесса, а также в последующем профессиональном развитии;

- в-третьих, овладение курсантом исчерпывающей информацией о особенностях, возможностях, и перспективах получаемого образования; ценностной и целевой профессиональной ориентации, содержании, структуре, предполагаемой результативности, возможных профессиональной неуспешности и ограничениях;

- в-четвёртых, приобретение курсантом навыков субъектного использования предлагаемых образовательных условий и возможностей для решения личностно значимых как профессионально-образовательных, так и жизненно-образовательных задач;

- в-пятых, самостоятельное проектирование курсантом индивидуально- и личностно-предназначенного образовательного маршрута

Индивидуальный профессионально-образовательный опыт курсанта, как будущего инспектора ПДН выражается в степени развитости: профессиональной компетентности; профессиональной умелости, мастерстве; готовности к профессиональному творчеству; ценностного отношения к будущей профессии и профессиональной деятельности.

Актуальный образовательный опыт представляет собой совокупность:

1. Образовательной компетентности, выражающейся: 
- в информированности курсанта о себе, своих образовательных, а в перспективе и в профессиональных потребностях и возможностях;

- в информированности курсанта о возможностях образования, образовательной системы, образовательной деятельности, образовательного процесса.

2. Умений решать актуальные образовательные задачи, что может быть связано:

- с умениями выделить и оценить личностную значимость для эффективного решения актуальных на различных этапах обучения задач;

- с умениями успешно самоопределиться в изменяющихся (изменившихся) социальных обстоятельствах и образовательных условиях с целью максимального их использования в процессе саморазвития как субъекта образования.

3. Умений проектирования индивидуально-личностного образовательного маршрута, которые складываются из умений курсанта: конструировать иерархически соподчиненную цепочку образовательных задач; выстраивать линию своего образования; устанавливать диалектические связи между перспективой, стратегией, тактикой, целями и оперативными задачами своего профессионального образования.

4. Личностных смыслов и субъектных отношений к профессиональному образованию как процессу и индивидуальной образовательной деятельности.

Показателями развития субъектной позиции студента в процессе обучения в вузе будут являться компоненты образовательного опыта. В частности, обретение личностных смыслов и ценностного отношения к профессиональному образованию; необходимая и достаточная информированность о своих возможностях и возможностях образовательной организации; компетентность в решении образовательно-профессиональных задач; умения моделировать и проектировать индивидуально-личностный профессионально-образовательный маршрут.

Характер выраженности этих показателей может:

- свидетельствовать об индивидуальном своеобразии субъектной позиции курсанта; степени готовности к освоению профессионально-образовательного опыта инспектора ПДН; 
- прогнозировать динамику развития субъектной позиции курсанта в образовании и динамику его личностно-профессионального становления, поскольку характер его будущей профессиональной деятельности, успешность профессиональной самореализации напрямую зависят от проявляемого ценностно-деятельностного отношения к действующим образовательным условиям, от характера и направленности субъектной позиции в образовании.

Обозначенные теоретические аспекты проблемы развития субъектной позиции курсанта профессионального вуза, позволяют отметить, что актуальность специального изучения феномена субъектной позиции обусловлена:

- характерными для современного общества тенденциями гуманизации и усилением личной ответственности человека за построение своего жизненного и профессионального пути;

- общенаучными, философскими тенденциями рассмотрения человека как уникально-неповторимой ценности, результата и источника развития профессиональной культуры и сферы профессиональной деятельности.

Реалии современного социокультурного и образовательного пространства обусловливают проявления личности, субъектности, деятельности - субъектной позиции курсанта как необходимое и достаточное: условие его профессионального образования, саморазвития и самореализации в социально-педагогической деятельности как инспектора ПДН органах внутренних дел, а также как необходимое условие успешности функционирования самой системы профессионального образования.

\section{Список литературы}

1. Душкин А.С. Психологическое сопровождение профилактической деятельности сотрудников органов внутренних дел подразделений по делам несовершеннолетних: Автореф. дисс. ... канд. психол. наук. - СПб., 2010.

2. Кузьмичева Н.А. Теоретическая модель профессиограммы инспектора по делам несовершеннолетних // Психология и педагогика служебной деятельности - 2016. - №2. - С. 36-42.

3. Маркова А.К. Психология профессионализма. - М.: Знание, 1996. 
4. Профессиографическое описание деятельности психологов МВД России на основе компетентностного подхода: Отчет о НИР / Л. Цветков, С.Н. Федотов, Т.А. Хрусталева [и др.] - М.: Моск. ун-т МВД Росии, 2014.

5. Федеральный государственный образовательный стандарт специальности 44.05.01 - Педагогика и психология девиантного поведения (специализация Социальная педагогика) [Электронный ресурс].- Режим доступа: http://www.birsk.ru/system/files/vpo_direct/fgos.zip

Ковров Владимир Викентьевич - канд. пед. наук, доцент, доцент кафедры педагогики Учебно-научного комплекса психологии служебной деятельности ФГКОУ ВО «Московский университет МВД России им. В.Я. Кикотя», Россия, Москва.

Kovrov Vladimir Vikentievich - candidate of pedagogical sciences, associate professor, associate professor of the Department of Pedagogy of Training and Research Complex of Performance Psychology, FSPEE of HE "Moscow University of the Ministry of Internal Affairs of the Russian Federation named after V.Y. Kikot", Russia, Moscow. 